\title{
Correction:Acquired hemophilia as the cause of life-threatening hemorrhage in a 94-year-old man: a case report
}

Theodoros Kelesidis", Jonelle Raphael, Elizabeth Blanchard

\section{Correction}

The list of authors of this article [1] was incorrect as published and should be as follows: Theodoros Kelesidis, Jonelle Raphael and Elizabeth Blanchard.

Rekha Parameswaran did not approve the final version of the manuscript for publication and does not wish to be included as an author. In addition, Elizabeth Blanchard's initials appeared incorrectly as $\mathrm{BE}$ in the authors' contributions section. This section should read as follows:

TK analyzed and interpreted the patient data and was a major contributor in writing the manuscript. JR analyzed the patient data and contributed in writing the manuscript. EB analyzed and interpreted the patient data and was a major contributor in writing the manuscript. All authors read and approved the final manuscript.

Received: 21 February 2011 Accepted: 22 February 2011

Published: 22 February 2011

\section{Reference}

1. Kelesidis T, Raphael J, Blanchard E, Parameswaran R: Acquired hemophilia as the cause of life-threatening hemorrhage in a 94-year-old man: a case report. Journal of Medical Case Reports 2010, 4:231.

* Correspondence: tkelesid@gmail.com

Department of Medicine, Caritas St Elizabeth's Medical Center, Tufts

University School of Medicine, Boston, MA, USA

Submit your next manuscript to BioMed Central and take full advantage of:

- Convenient online submission

- Thorough peer review

- No space constraints or color figure charges

- Immediate publication on acceptance

- Inclusion in PubMed, CAS, Scopus and Google Scholar

- Research which is freely available for redistribution
C Biomed Central 